\title{
Gene Profile by Next Generation Sequencing (NGS) in Paediatric Acute Lymphoblastic Leukaemia (ALL), Diagnosis and Treatment Guidance
}

\author{
Maher Salamoon $^{1^{*}}$, Mehdi Balti ${ }^{2}$ \\ Department of hemato/oncology, Al Bairouni university cancer center, Hospital militaire principal d'instruction
}

*Corresponding Author: Maher Salamoon, Department of hemato/oncology, Al Bairouni university cancer center, Hospital militaire principal d'instruction, E-mail: maher.salamoon@gmail.com

\begin{abstract}
Acute lymphoblastic leukemia (ALL) accounts for $25 \%$ of adult leukemia and the most common cancer in children. Most children are doing well with the conventional chemotherapy, however there is no consensus about a definitive protocol because of the heterogeneity of both clones and genetic diversity. The implementation of next generation sequencing (NGS) has led to improvement of both understanding the genetic background of disease and the designation of new targeted therapies. The purpose of our review is to shed light about the gene profile in ALL patients and the current clinical trial examining new molecules on response to genetic findings and the future directions. Also, we will concentrate on the emerging role of NGS in minimal residual disease (MRD) assessment.
\end{abstract}

Keywords: acute lymphoblastic leukemia (ALL), next generation sequencing (NGS)

\section{INTRODUCTION}

Acute lymphoblastic leukemia (ALL) is the most frequent cancer in childhood (1) with $90 \%$ overall survival for 5 years (2) compared with $75-80 \%$ in adolescents (3). Adults ALL forms about $20-25 \%$ of adults leukemia presenting with different biologic aspects and it runs a different course with poor survival reaching $35 \%$ at 5 years (4). ALL originates from precursors of either B or T lymphocyte and it is triggered by an aberration like chromosomal translocation, gene mutations, aneuploidy in genes taking control on cell cycle progression and cell growth (5). Actually, treatment depends on multi agents chemotherapy in both pediatric and adult population which can be followed with allogeneic bone marrow transplantation in high risk groups (6). The emergence of new technologies in the diagnosis of ALL a $t$ a molecular level such as next generation sequencing (NGS) has led laboratories to design new therapeutic approach such as monoclonal antibodies [Blinatumumab and Inotuzumab which were approved by the food and drug administration (FDA) for the treatment of relapsed/refractory ALL] and chimeric antigen receptor of T-cell (CAR-T) which was approved in turn by FDA for the same former indication in both pediatrics and adults (7). Despite the efforts to increase survival rates in both in children and adults, relapse takes place in $20 \%$ of pediatrics versus $50 \%$ in adults where the prognosis becomes very poor $(8,9)$. Therefore, concentration has been made on the molecular basis of disease in order to help clinicians in risk stratification and personalized treatment as well. Genomic analysis is very crucial in diagnosis, risk stratification and treatment choices as well, and it is composed of two phases, the phase of discovery of genomic alteration and the practical phase where scientist can apply the finding as a therapeutic approach. The aim of this review is to explain the switch from the old pattern of genetic testing which was able to detect especially chromosomal translocations, however, there will be still rare and masked alterations which cannot be recognized by the available methods such as Fluorescence in situ hybridization (FISH) or polymerase chain reaction (PCR).

\section{Biologic Alterations In ALL}

\subsection{Dux4/Erg All}

DUX4 aberration was discovered in a B-ALL sub-clone with a frequency of about 4-7\%. In most cases, it was found to be over-expressed along with deregulation or deletion of the transcription factor ERG (11). DUX4 fusions are found with deletion in IKZF1, PAX5 and CDKN2A/CDKN2B. It can also be accompanied 
with activating mutations in NRAS, KRAS, MYC, MYCBP2, MGA and ZEB2 (12).

\subsection{Etv6/Runx1 Like All}

This new entity of ALL is characterized by aberration in both ETV6 and IKZF1 and it has same gene profile found in DUX1/ERG ALL (11). All cases with ETV6/RUNX1 show aberration in ETV6 and CD27 high/ CD44 low expression by flow cytometry (13). Researchers confirmed that about 3-5\% of newly diagnosed cases of BCP-ALL belong to this new biologic category which will positively impact the risk stratification.

\subsection{Mef2d/Znf384 All}

The fusion MEF2D/ZNF384 is found in $7 \%$ of adults ALL versus about $3.6 \%$ in pediatrics. MEF2D has several fusions, one of the most important one leads to an up-regulation of HDAC9 (14) leading to B cell lineage damage and suppression of B-lineage genes RAG1 (15). It was found that, when MEF2D transcription is up-regulated, the expression of HDAC9 is activated leading to increasing the sensitivity to histone deacetylase inhibitor which could be a new treatment choice in this setting (16). In the other hand, ZNF384 showed less fusion with minor role in $\mathrm{B}$ cell maturation or cell cycle control. The most important fusions were ZNF384-EP300 and ZNF384-CREBBP which use an epigenetic function to alter the hematopoietic stimulation of leukemic transformation which could be attributed in a part to reduction in histone acetylation making this clone a good candidate for treatment with histone deacetylase inhibitor (17).

\subsection{Tcf3/Hlf All}

Using NGS techniques, Fisher et al demonstrated that TCF3/HLF ALL patients show a very bad prognosis when the fusion is accompanied with PAX5 haplo-insufficiency. This combination leads to the formation of immature resistant cells. Pharmaceutical studies demonstrated response to corticosteroids, anthracyclins and more recently the BCL-2 inhibitor (venetoclax) (18).

\subsection{MLL Rearranged (MLL-R) ALL}

This type represents a very aggressive subtype of mixed lineage leukemia (MLL) with rearrangement. Children with MLL-R ALL show low levels of somatic mutation may be because of the domination of the extreme powerful activity of the oncogenic function of the MLL protein. Few mutations were observed in the PI3K/RAS pathway conferring the cross talk between this pathway and MLL protein. Older children show more somatic mutation especially in the regulatory regions of epigenetic level, however, these mutation disappear upon relapse (19).

\subsection{EPOR Gene Rearrangement}

A Philadelphia (PH-like ALL) is characterized by rearrangement of the erythropoietin receptor gene. In a study performed on more than 300 patients with PH-like ALL, Iacobucci et al demonstrated that 212 patients only found to have a truncated erythropoietin receptor leading to increased sensitivity to erythropoietin and hyper-activation of JAK/STAT pathway. The former alteration was also accompanied with aberration in CDKN2A/CDKN2B, IKZF1 and PAX5 genes. This finding may direct treatment towards JAK/STAT inhibitor (20).

\subsection{Aneuploid All}

Aneuploidy and hyperploidy are the hallmark of patients with ALL. Hyperploidy is observed in one third of newly diagnosed children with ALL with more than 50 chromosomes. In this case, RTK/RAS pathway is involved and histone function modifiers as well, however, fusion genes are found in a minority of patients. Chromosome gains are found in early stages of disease forming the most important driver event compared with hypodiploidy with chromosomes less than 44 found in only $3 \%$ of patients as an early event (21). Patients having between 25-30 chromosomes show mutations in IKZF3 and FLT-3, where patients having between 31-39 chromosomes show mutations in TP53

\section{NEW FUSION GENES REVEALED}

In 2018, a study published by Chen et al, revealed 36 new fusions, 18 out of which are new fusions (ZBTB16-ABL1, TRA-SALL2, and NKX2-1 rearrangements) mainely found in recurrent diseases (23). ZBTB16 is a hematopoietic regulator gene and it was mentioned as a partner of RARA discovered in acute promyelocytic leukemia (APL) (24). In case of ZBTB16-ABL1 fusion, the SH2 and SH2 domains of ABL1 keep their high tyrosin kinase activity leading to high proliferative index (25). TAL1 was found to be up-regulated in a pediatric cohort. The study has also demonstrated that the coincident overexpression of both SPI1 and MEF2C plays a role in normal lymphoid development; however, 
Gene Profile by Next Generation Sequencing (NGS) in Paediatric Acute Lymphoblastic Leukaemia (ALL), Diagnosis and Treatment Guidance

dysregulation of this pathway may play a role in leukemia development (26).

Table1. Current studies in B-ALL with the main findings

\begin{tabular}{|c|c|c|c|}
\hline Study author & Cases studied & NGS type & findings \\
\hline $\begin{array}{l}\text { Safavi et al., } \\
2015 \text { (21) }\end{array}$ & $\begin{array}{l}11 \\
\text { hypodiploid } \\
\text { B-ALL }\end{array}$ & $\begin{array}{l}\text { WES, RNA- } \\
\text { Seq }\end{array}$ & $\begin{array}{l}\text { IKZF3 and FLT3 mutations in near-haploid }(25-30 \mathrm{chr}) \\
\text { cases; TP53 mutations in low hypodiploidy }(31-39 \mathrm{chr}) \\
\text { and hypodiploid }(40-4 \mathrm{chr}) \text { cases. }\end{array}$ \\
\hline $\begin{array}{l}\text { Paulsson et } \\
\text { al., } \\
2015(27)\end{array}$ & $\begin{array}{l}51 \quad \text { High } \\
\text { hyperdiploid } \\
\text { B-ALL }\end{array}$ & $\begin{array}{l}\text { WGS and } \\
\text { WES }\end{array}$ & $\begin{array}{l}\text { Frequent involvement of the RTK-RAS pathway and of } \\
\text { histone modifiers. No recurrent fusion gene-forming } \\
\text { rearrangement found. The chromosomal gains were early } \\
\text { events. }\end{array}$ \\
\hline $\begin{array}{l}\text { Fischer et al., } \\
2015 \text { (18) }\end{array}$ & $\begin{array}{l}\text { TCF3- } \\
\text { HLF } \square \text { positive } \\
\text { B-ALL }\end{array}$ & $\begin{array}{l}\text { WGS, WES } \\
\text { and } \\
\text { RNA-Seq }\end{array}$ & $\begin{array}{l}\text { Identification of recurrent intragenic deletions of PAX5 } \\
\text { or VPREB } 1 \text {, somatic mutations in the non-translocated } \\
\text { allele of TCF3 and a reduction of PAX5 gene dosage in } \\
\text { addition to TCF3-HLF fusion. }\end{array}$ \\
\hline $\begin{array}{l}\text { Messina et } \\
\text { al., } \\
2016(28)\end{array}$ & $\begin{array}{l}168 \text { B-ALL } \\
\text { lacking } \\
\text { known fusion } \\
\text { transcripts }\end{array}$ & $\begin{array}{l}\text { WES and } \\
\text { targeted } \\
\text { NGS }\end{array}$ & $\begin{array}{l}\text { Identification of } 10.5 \text { mutations and } 9.1 \text { CNAs /sample. } \\
\text { The most frequently mutated pathways were RAS/RTK } \\
(26.8 \%) \text { and JAK/STAT }(12.5 \%) \text { signaling. }\end{array}$ \\
\hline $\begin{array}{l}\text { Liu et al., } \\
2016(15)\end{array}$ & 203 B-ALL & $\begin{array}{l}\text { WGS, RNA- } \\
\text { Seq and } \\
\text { Targeted deep } \\
\text { sequencing }\end{array}$ & $\begin{array}{l}\text { Identification of } 29 \text { new in-frame gene fusions and eight } \\
\text { gene expression subgroups associated with characteristic } \\
\text { genetic abnormalities: (MEF2D fusions, TCF3-PBX1 } \\
\text { fusions, ETV6-RUNX1-positive/ETV6-RUNX1-like, } \\
\text { DUX4 fusions, ZNF384 fusions, BCR-ABL1/Ph-like, } \\
\text { high hyperdiploidy, and KMT2A fusions). }\end{array}$ \\
\hline $\begin{array}{l}\mathrm{Gu} \text { et al., } \\
2016(16)\end{array}$ & 560 B-ALL & RNA-Seq & $\begin{array}{l}\text { Identification of rearrangements between MEF2D } \\
\text { (myocyte enhancer factor 2D) and five partner genes } \\
\text { (BCL9, CSF1R, DAZAP1, HNRNPUL1, SS18). } \\
\text { MEF2D-rearranged cases comprise 5.3\% of ALL cases } \\
\text { lacking recurring alterations and represent a distinct form } \\
\text { of high-risk leukaemia. }\end{array}$ \\
\hline
\end{tabular}

Illustrates current trials in B-ALL with the main findings using different NGS technologies

Table2. Illustrates the frequency of gene mutations in B-ALL patients detected by NGS ad the current treatment approaches along with the ongoing clinical trials basing on NGS results

\begin{tabular}{|l|l|l|}
\hline Mutated gene & Frequency & \multicolumn{1}{c|}{ Current trial and treatment approach } \\
\hline ABL1 & $1.29 \%$ & Blinatumomab,inotuzumab ozogamicin \\
\hline ABL2 & NA & Blinatumomab, dasatinib and mercaptopurine \\
\hline AFF1 & NA & $\begin{array}{l}\text { Binatumomab,cyclophosphamide and cytarabine, fludarabine, mycophenolate } \\
\text { mofetil }\end{array}$ \\
\hline ASXL1 & $3.45 \%$ & Ect-001 expanded cord blood and allogeneic stem cell transplantation \\
\hline ATM & $4.79 \%$ & MLN9708, allogeneic stem cell transplantation and cyclophosphamide \\
\hline BCR & NA & $\begin{array}{l}\text { Blinatumomab, inotuzumab ozogamicin and prednisolone, bosutinib, dasatinib, } \\
\text { ponatinib, imatinib, nilotinib }\end{array}$ \\
\hline BIRC3 & NA & MLN9708, allogeneic tem cell transplantation and cyclophosphamide \\
\hline CBFA2T3 & NA & $\begin{array}{l}\text { Allogeneic specific allogeneic type 1 regulatory T-cells t-allo 10, non- } \\
\text { myeloablativeTCR alpha/beta depleted haploidentical stem cell transplantation }\end{array}$ \\
\hline CBFB & NA & Fludarabine, total body irradiation and cyclophosphamide \\
\hline CBL & $0.44 \%$ & Dexamethasone and selumetinib \\
\hline CREBBP & $8.63 \%$ & $\begin{array}{l}\text { Allogeneic specific allogeneic type 1 regulatory T-cells t-allo 10, non- } \\
\text { myeloablative TCR alpha/beta depleted haploidentical stem cell transplantation } \\
\text { and rabbit anti-thymocyte globulin }\end{array}$ \\
\hline CRLF2 & NA & Blinatumomab, dasatinib, and mercaptopurine \\
\hline CSF1R & $1.2 \%$ & $\begin{array}{l}\text { Blinatumomab, dasatinib and mercaptopurine, ect-001 expanded cord blood, } \\
\text { asparginase }\end{array}$ \\
\hline DEK & NA & Fludarabine, cyclophosphamide and mycophenolate mofetil \\
\hline ELL & NA & Fludarabine, cyclophosphamide and total body irradiation \\
\hline EPOR & NA & $\begin{array}{l}\text { Blinatumomab, dasatinib and mercaptopurine, ect-001 expanded cord blod, } \\
\text { asparginase }\end{array}$ \\
\hline ERBB2 & $0.68 \%$ & Ror1 CAR-specific autologous T-lymphocytes \\
\hline ERG & $3.19 \%$ & Allo-antigen specific alloantigen type 1 regulatory T cels t-allo 10 \\
\hline ETV6 & $4.42 \%$ & Non-myeloablative TCR alpha/beta depleted haploidentical stem cel \\
\hline
\end{tabular}


Gene Profile by Next Generation Sequencing (NGS) in Paediatric Acute Lymphoblastic Leukaemia (ALL), Diagnosis and Treatment Guidance

\begin{tabular}{|c|c|c|}
\hline & & transplantation \\
\hline FGFR1 & NA & Blinatumomab, dasatinib and mercaptopurine \\
\hline FGFR2 & NA & Blinatumomab, dasatinib and mercaptopurine \\
\hline FGFR3 & $0.68 \%$ & CDK/JAK/FLT3 inhibitorMLN9708 \\
\hline FLT3 & NA & $\begin{array}{l}\text { Blinatumomab, dasatinib and mercaptopurine, fludarabine, cyclophosphamide } \\
\text { and total body irradiation }\end{array}$ \\
\hline GLIS2 & NA & Non-myeloablative TCR alpha/beta depleted haploidentical stem cel transplantation \\
\hline HOXA9 & NA & Non-myeloablative TCR alpha/beta depleted haploidentical stem cel transplantation \\
\hline HRAS & $0.86 \%$ & Antineoplastic immune cells, ect-001 expanded cord blood \\
\hline IGK & NA & Blinatumomab, inotuzumab ozogamicin \\
\hline IGH & NA & $\begin{array}{l}\text { Blinatumomab, inotuzumab ozogamicin, fluydarabine, cyclophosphamide and } \\
\text { CDK/JAK/FLT3 inhibitor }\end{array}$ \\
\hline IKZF1 & $4.05 \%$ & Blinatumomab, fludarabine, cyclophosphamide \\
\hline IL7R & NA & Blinatumomab, dasatinib and mercaptopurine, ect-01 expanded cord blood \\
\hline JAK1 & $10 \%$ & $\begin{array}{l}\text { Blinatumomab, dasatinib and mercaptopurine, ect-001 expanded cord } \\
\text { blod,asparginase }\end{array}$ \\
\hline JAK2 & $2.58 \%$ & $\begin{array}{l}\text { Blinatumomab, dasatinib and mercaptopurine, antineoplastic immune cells, } \\
\text { leucovorin, thioguanine }\end{array}$ \\
\hline JAK3 & $1.13 \%$ & $\begin{array}{l}\text { Blinatumomab, dasatinib and mercaptopurine, ect-001 expanded cord blood, } \\
\text { asparginase }\end{array}$ \\
\hline KAT6A & $3.45 \%$ & Non-myeloablative TCR alpha/beta depleted haploidentical stem cel transplantation \\
\hline KMT2A & $2.7 \%$ & Blinatumomab, cyclophosphamide and cytarabine and total body irradiation \\
\hline KDM5A & NA & Non-myeloablative TCR alpha/beta depleted haploidentical stem cel transplantation \\
\hline KIT & $0.86 \%$ & Fludarabine, cyclophosphamide and total body irradiation \\
\hline KRAS & $9.87 \%$ & $\begin{array}{l}\text { Antineoplastic immune cells, ect-001 expanded cord blood and alloeneic stem } \\
\text { cells transplantation }\end{array}$ \\
\hline MDM2 & $0.72 \%$ & MDM2/MDMX inhibitor ALRN-6924 and cytarabine \\
\hline MDM4 & NA & MDM2/MDMX inhibitor ALRN-6924 and cytarabine \\
\hline MECOM & $3.94 \%$ & Fludarabine, cyclophosphamide and total body irradiation \\
\hline MLF1 & NA & Fludarabine, cyclophosphamide and total body irradiation \\
\hline MLLT3 & NA & Blinatumomab \\
\hline MNX1 & NA & Non-myeloablative TCR alpha/beta depleted haploidentical stem cel transplantation \\
\hline MYC & $2.16 \%$ & Allogeneic stem cell transplantation,busulfan and cyclophosphamide \\
\hline MYH1 & NA & Fludarabine and total body irradiation \\
\hline NPM1 & $0.43 \%$ & Fludarabine, cyclophosphamide and total body irradiation \\
\hline NRAS & $12.45 \%$ & $\begin{array}{l}\text { Antineoplastic immune cells, ect-001 expanded cord blood and allogeneic stem } \\
\text { cell transplantation }\end{array}$ \\
\hline NSD1 & NA & $\begin{array}{lllllll}\begin{array}{l}\text { Non-myeloablative } \\
\text { transplantation }\end{array} & \text { TCR } & \text { alpha/beta } & \text { depleted } & \text { haploidentical } & \text { stem } & \text { cel } \\
\end{array}$ \\
\hline NUP98 & NA & $\begin{array}{lllllll}\begin{array}{l}\text { Non-myeloablative } \\
\text { transplantation }\end{array} & \text { TCR } & \text { alpha/beta } & \text { depleted } & \text { haploidentical } & \text { stem } & \text { cel } \\
\end{array}$ \\
\hline PBX1 & NA & Blinatumomab , fludarabin and cyclophosphamide \\
\hline PDGFRA & NA & Blinatumomab, dasatinib andmercaptopuriney \\
\hline PDGFRB & $2.16 \%$ & $\begin{array}{l}\text { Blinatumomab, dasatinib and mercaptopurine, ect-001 expanded cord blood, } \\
\text { asparginase }\end{array}$ \\
\hline PTPN11 & $3.86 \%$ & Dexamethasone and selumetinib \\
\hline RARA & 0.72 & WT1 analog peptide vaccine \\
\hline RUNX1 & $4.87 \%$ & Fludarabine, cyclophosphamide and total body irradiation \\
\hline SH2B3 & NA & Blinatumomab, dasatinib and mercaptopurine \\
\hline SF3B1 & $0.44 \%$ & MLN9708, allogeneic stem cell transplantation \\
\hline TCF3 & $3.12 \%$ & Fludarabine and cyclophosphamide \\
\hline TET2 & $5.31 \%$ & MDM2/MDMX inhibitor and cytarabine \\
\hline TP53 & $7.3 \%$ & Fludarabine, cyclophosphamide and total body irradiation \\
\hline TRA & NA & Blinatumomab , IL-15 activated cytokine induced killer cells \\
\hline TRB & NA & Blinatumomab , IL-15 activated cytokine induced kiler cells \\
\hline TRD & NA & Blinatumomab, IL-15 activated cytokine induced kiler cells \\
\hline TRG & NA & Blinatumomab, IL-15 activated cytokine induced kiler cells \\
\hline WHSC1 & $3.45 \%$ & MLN0708, allogeneic stem cell transplantation and cyclophosphamide \\
\hline WT1 & $2.65 \%$ & Non-myeloablative TCR alpha/beta depleted haploidentical stem cel transplantation \\
\hline
\end{tabular}

demonstrate all isolated genes known to be mutated in patients with B-ALL, in the left column genes are mentioned, in the second one gene frequency is illustrated and the 3rd column mentions the current approved drug or the current clinical trials targeting the gene of interest. 


\section{CONCLUSION}

NGS offers tremendous amounts of information at both genetic and epigenetic levels, however, transforming these information into practice is really challenging. For example, ALL has its own risk stratification depending on age, sex, white blood cell count at presentation, chromosomal aberration, and involvement of the central nervous system and level of MRD burden. In the case of ALL, obtained information is had to be employed in risk assessment nowadays because gene mutations are various and some of them play a role in recurrence, others in drug resistance, signal transduction pathway activation and clonal evolution. For all these reasons, it is complicated to allocate every gene in the proper place regarding its function. However, there is a consensus that NGS is offering information that is important in diagnosis, prognosis and treatment decision making (29). In our days and future, efforts should be made to get benefit from all NGS technologies and implement of the knowledge taken from in designation of international guideline for diagnosis, treatment and monitoring of MRD.

\section{REFERENCES}

[1] Mullighan, C.G.; Goorha, S.; Radtke, I.; Miller, C.B.; Coustan-Smith, E.; Dalton, J.D.; Girtman, K.; Mathew, S.; Ma, J.; Pounds, S.B.; et al. Genome-wide analysis of genetic alterations in acute lymphoblastic leukaemia. Nature 2007, 446, 758-764.

[2] Santiago, R.; Vairy, S.; Sinnett, D.; Krajinovic, M.; Bittencourt, H. Novel therapy for childhood acute lymphoblastic leukemia. Expert Opin. Pharmacother. 2017, 18, 1081-1099.

[3] Smith, M.A.; Seibel, N.L.; Altekruse, S.F.; Ries, L.A.G.; Melbert, D.L.; O'Leary, M.; Smith, F.O.; Reaman, G.H. Outcomes for children and adolescents with cancer: Challenges for the twenty-first century. J. Clin. Oncol. 2010, 28, 2625-2634.

[4] Gökbuget, N.; Kneba, M.; Ra_, T.; Trautmann, H.; Bartram, C.-R.; Arnold, R.; Fietkau, R.; Freund, M.; Ganser, A.; Ludwig,W.-D.; et al. Adult patients with acute lymphoblastic leukemia and molecular failure display a poor prognosis and are candidates for stem cell transplantation and targeted therapies. Blood 2012, 120, 1868-1876.

[5] Hunger, S.P.; Mullighan, C.G. Acute Lymphoblastic Leukemia in Children. N. Engl. J. Med. 2015, 373, 1541-1552.
[6] Terwilliger, T.; Abdul-Hay, M. Acute lymphoblastic leukemia: A comprehensive review and 2017 update. Blood Cancer J. 2017, 7, e577.

[7] Bassan, R.; Bourquin, J.-P.; DeAngelo, D.J.; Chiaretti, S. New Approaches to the Management of Adult Acute Lymphoblastic Leukemia. J. Clin. Oncol. 2018, 36, 3504-3519.

[8] Fielding, A.K.; Richards, S.M.; Chopra, R.; Lazarus, H.M.; Litzow, M.R.; Buck, G.; Durrant, I.J.; Luger, S.M.; Marks, D.I.; Franklin, I.M.; et al. Outcome of 609 adults after relapse of acute lymphoblastic leukemia (ALL); an MRC UKALL12/ECOG 2993 study. Blood 2007, 109, 944-950.

[9] Einsiedel, H.G.; von Stackelberg, A.; Hartmann, R.; Fengler, R.; Schrappe, M.; Janka-Schaub, G.; Mann, G.; Hählen, K.; Göbel, U.; Klingebiel, T.; et al. Long-term outcome in children with relapsed ALL by riskstratified salvage therapy: Results of trial acute lymphoblastic leukemia-relapse study of the Berlin-Frankfurt-Münster Group 87. J. Clin. Oncol. 2005, 23, 7942-7950.

[10] Inaba, H.; Greaves, M.; Mullighan, C.G. Acute lymphoblastic leukaemia. Lancet 2013, 381, 1943-1955.

[11] Lilljebjörn, H.; Henningsson, R.; HyreniusWittsten, A.; Olsson, L.; Orsmark-Pietras, C.; von Pal_y, S.; Askmyr, M.; Rissler, M.; Schrappe, M.; Cario, G.; et al. Identification of ETV6-RUNX1-like and DUX4-rearranged subtypes in paediatric B-cell precursor acute lymphoblastic leukaemia. Nat. Commun. 2016, 7, 11790 .

[12] Zhang, J.; McCastlain, K.; Yoshihara, H.; Xu, B.; Chang, Y.; Churchman, M.L.; Wu, G.; Li, Y.; Wei, L.; Iacobucci, I.; et al. Deregulation of DUX4 and ERG in acute lymphoblastic leukemia. Nat. Genet. 2016, 48, 1481-1489.

[13] Vaskova, M.; Mejstrikova, E.; Kalina, T.; Martinkova, P.; Omelka, M.; Trka, J.; Stary, J.; Hrusak, O. Transfer of genomics information to flow cytometry: Expression of CD27 and CD44 discriminates subtypes of acute lymphoblastic leukemia. Leukemia 2005, 19, 876-878.

[14] Haberland, M.; Montgomery, R.L.; Olson, E.N. The many roles of histone deacetylases in development and physiology: Implications for disease and therapy. Nat. Rev. Genet. 2009, 10, 32-42.

[15] Liu, Y.-F.;Wang, B.-Y.; Zhang,W.-N.; Huang, J.-Y.; Li, B.-S.; Zhang, M.; Jiang, L.; Li, J.F.;Wang, M.-J.; Dai, Y.-J.; et al. Genomic Profiling of Adult and Pediatric B-cell Acute Lymphoblastic Leukemia. EBioMedicine 2016, 8, 173-183.

[16] Gu, Z.; Churchman, M.; Roberts, K.; Li, Y.; Liu, Y.; Harvey, R.C.; McCastlain, K.; Reshmi, 
S.C.; Payne-Turner, D.; Iacobucci, I.; et al. Genomic analyses identify recurrent MEF2D fusions in acute lymphoblastic leukaemia. Nat. Commun. 2016, 7, 13331.

[17] Qian, M.; Zhang, H.; Kham, S.K.-Y.; Liu, S.; Jiang, C.; Zhao, X.; Lu, Y.; Goodings, C.; Lin, T.-N.; Zhang, R.; et al. Whole-transcriptome sequencing identifies a distinct subtype of acute lymphoblastic leukemia with predominant genomic abnormalities of EP300 and CREBBP. Genome Res. 2017, 27, 185-195.

[18] Fischer, U.; Forster, M.; Rinaldi, A.; Risch, T.; Sungalee, S.; Warnatz, H.-J.; Bornhauser, B.; Gombert, M.; Kratsch, C.; Stütz, A.M.; et al. Genomics and drug profiling of fatal TCF3HLF-positive acute lymphoblastic leukemia identifies recurrent mutation patterns and therapeutic options. Nat. Genet. 2015, 47, 1020-1029.

[19] Tamai, H.; Miyake, K.; Takatori, M.; Miyake, N.; Yamaguchi, H.; Dan, K.; Shimada, T.; Inokuchi, K. Activated K-Ras protein accelerates human MLL/AF4-induced leukemo-lymphomo genicity in a transgenic mouse model. Leukemia 2011, 25, 888-891.

[20] Iacobucci, I.; Li, Y.; Roberts, K.G.; Dobson, S.M.; Kim, J.C.; Payne-Turner, D.; Harvey, R.C.; Valentine, M.; McCastlain, K.; Easton, J.; et al. Truncating Erythropoietin Receptor Rearrangements in Acute Lymphoblastic Leukemia. Cancer Cell 2016, 29, 186-200.

[21] Safavi, S.; Olsson, L.; Biloglav, A.; Veerla, S.; Blendberg, M.; Tayebwa, J.; Behrendtz, M.; Castor, A.; Hansson, M.; Johansson, B.; et al. Genetic and epigenetic characterization of hypodiploid acute lymphoblastic leukemia. Oncotarget 2015, 6, 42793-42802.

[22] Holmfeldt, L.; Wei, L.; Diaz-Flores, E.; Walsh, M.; Zhang, J.; Ding, L.; Payne-Turner, D.; Churchman, M.; Andersson, A.; Chen, S.C.; et al. The genomic landscape of hypodiploid acute lymphoblastic leukemia. Nat. Genet. 2013, 45, 242-252.
[23] Chen, B.; Jiang, L.; Zhong, M.-L.; Li, J.-F.; Li, B.-S.; Peng, L.-J.; Dai, Y.-T.; Cui, B.-W.; Yan, T.-Q.; Zhang, W.-N.; et al. Identification of fusion genes and characterization of transcript me features in T-cell acute lymphoblastic leuk emia. Proc. Natl. Acad. Sci. USA 2018, 115, $373-378$.

[24] Chen, Z.; Brand, N.J.; Chen, A.; Chen, S.J.; Tong, J.H.;Wang, Z.Y.;Waxman, S.; Zelent, A. Fusion between a novel Krüppel-like zinc finger gene and the retinoic acid receptor-alpha locus due to a variant $\mathrm{t}(11 ; 17)$ translocation associated with acute promyelocytic leukaemia. EMBO J. 1993, 12, 1161-1167.

[25] Daley, G.Q.; Van Etten, R.A.; Baltimore, D. Induction of chronic myelogenous leukemia in mice by the P210bcr/abl gene of the Philadelphia chromosome. Science 1990, 247, 824-830.

[26] Chen, B.; Jiang, L.; Zhong, M.-L.; Li, J.-F.; Li, B.-S.; Peng, L.-J.; Dai, Y.-T.; Cui, B.-W.; Yan, T.-Q.; Zhang, W.-N.; et al. Identification of fus ion genes and characterization of transcript tome features in T-cell acute lympho blastic leukemia. Proc. Natl. Acad. Sci. USA 2018, 115, 373-378.

[27] Paulsson, K.; Lilljebjörn, H.; Biloglav, A.; Olsson, L.; Rissler, M.; Castor, A.; Barbany, G.; Fogelstrand, L.; Nordgren, A.; Sjögren, H.; et al. The genomic landscape of high hyperdiploid childhood acute lymphoblastic leukemia. Nat. Genet. 2015, 47, 672-676.

[28] Messina, M.; Chiaretti, S.;Wang, J.; Fedullo, A.L.; Peragine, N.; Gianfelici, V.; Piciocchi, A.; Brugnoletti, F.; Di Giacomo, F.; Pauselli, S.; et al. Prognostic and therapeutic role of targetable lesions in B-lineage acute lymphoblastic leukemia without recurrent fusion genes. Oncotarget 2016, 7, 13886-13901.

[29] Mullighan, C.G. The molecular genetic makeup of acute lymphoblastic leukemia. Hematol. Am. Soc. Hematol. Educ. Progr. 2012, 2012, 389396.

Citation: Maher Salamoon, Mehdi Balti, Gene Profile by Next Generation Sequencing (NGS) in Paediatric Acute Lymphoblastic Leukaemia (ALL), Diagnosis and Treatment Guidance. ARC Journal of Pediatrics.2019; 5(2):4-9. doi:dx.doi.org/10.20431/2455-5711.0502002.

Copyright: (C) 2019 Authors. This is an open-access article distributed under the terms of the Creative Commons Attribution License, which permits unrestricted use, distribution, and reproduction in any medium, provided the original author and source are credited. 